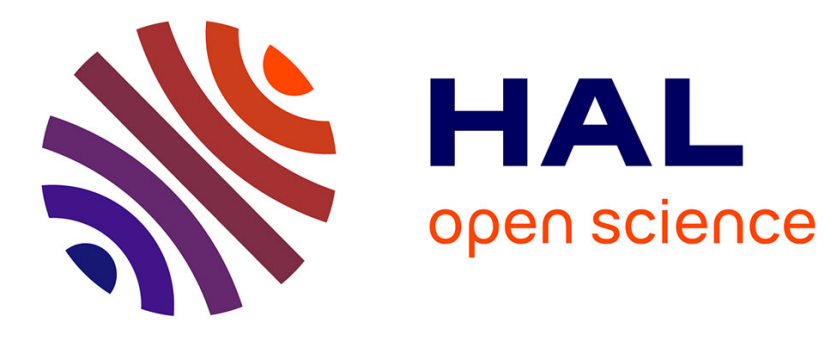

\title{
Synthesis of CuInS2 nanometric powder by reaction in molten KSCN
}

Mohamed Benchikhi, Rachida El Ouatib, Sophie Guillemet-Fritsch, Jean-Yves Chane-Ching, Jean-Jacques Demai, Lahcen Er-Rakho, Bernard Durand

\section{- To cite this version:}

Mohamed Benchikhi, Rachida El Ouatib, Sophie Guillemet-Fritsch, Jean-Yves Chane-Ching, JeanJacques Demai, et al.. Synthesis of CuInS2 nanometric powder by reaction in molten KSCN. Materials Letters, 2014, vol. 136, pp. 431-434. 10.1016/j.matlet.2014.08.101 . hal-01169233

\section{HAL Id: hal-01169233 \\ https://hal.science/hal-01169233}

Submitted on 29 Jun 2015

HAL is a multi-disciplinary open access archive for the deposit and dissemination of scientific research documents, whether they are published or not. The documents may come from teaching and research institutions in France or abroad, or from public or private research centers.
L'archive ouverte pluridisciplinaire $\mathbf{H A L}$, est destinée au dépôt et à la diffusion de documents scientifiques de niveau recherche, publiés ou non, émanant des établissements d'enseignement et de recherche français ou étrangers, des laboratoires publics ou privés. 


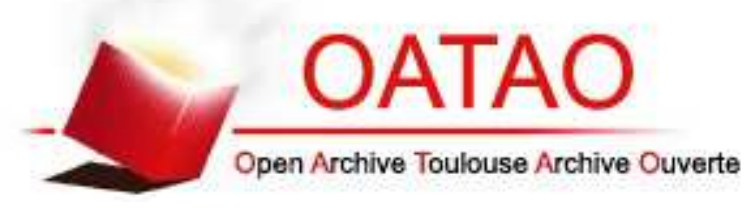

\section{Open Archive TOULOUSE Archive Ouverte (OATAO)}

OATAO is an open access repository that collects the work of Toulouse researchers and makes it freely available over the web where possible.

This is an author-deposited version published in : http://oatao.univ-toulouse.fr/ Eprints ID : 14122

To link to this article : doi: $10.1016 /$ j.matlet.2014.08.101

URL : http://dx.doi.org/10.1016/j.matlet.2014.08.101

To cite this version : Benchikhi, Mohamed and Ouatib, Rachida El and Guillemet-Fritsch, Sophie and Chane-Ching, Jean-Yves and Demai, Jean-Jacques and Er-Rakho, Lahcen and Durand, Bernard Synthesis of CuInS2 nanometric powder by reaction in molten KSCN. (2014) Materials Letters, vol. 136. pp. 431-434. ISSN 0167-577X

Any correspondance concerning this service should be sent to the repository administrator: staff-oatao@ listes-diff.inp-toulouse.fr 


\title{
Synthesis of CuInS 2 nanometric powder by reaction in molten KSCN
}

\author{
Mohamed Benchikhi ${ }^{\mathrm{a}, \mathrm{b}}$, Rachida El Ouatib ${ }^{\mathrm{a}}$, Sophie Guillemet-Fritsch ${ }^{\mathrm{b}}$, \\ Jean Yves Chane-Ching ${ }^{\mathrm{b}}$, Jean Jacques Demai ${ }^{\mathrm{b}}$, Lahcen Er-Rakho ${ }^{\mathrm{a}}$, Bernard Durand ${ }^{\mathrm{b}, *}$ \\ ${ }^{a}$ Laboratoire de Physico-Chimie des Matériaux Inorganiques, Université Hassan II Casablanca, Marocco \\ ${ }^{\mathrm{b}}$ Institut Carnot CIRIMAT, CNRS Université de Toulouse, 118 route de Narbonne, 31062 Toulouse Cedex 9, France
}

\section{A B S T R A C T}

$\mathrm{CuInS}_{2}$ was synthesized, with a yield of $70 \%$ by reaction in molten $\mathrm{KSCN}$ at $400{ }^{\circ} \mathrm{C}$ of $\mathrm{CuCl}_{2}$ and $\mathrm{InCl}_{3}$ with a ratio $\mathrm{KSCN} / \mathrm{Cu}=15$. The homogeneous powder obtained is constituted of nano-sized grains (70-100 nm), with a specific surface area of $6 \mathrm{~m}^{2} / \mathrm{g}$ and a band gap Eg of $1.5 \mathrm{eV}$.

Keywords:

Chalcogenide

Semiconductor

Molten salt

Nanoparticles

\section{Introduction}

An intensive research was carried out on ternary I-III-VI and quaternary I-II-IV- $\mathrm{VI}_{2}$ chalcogenides of chalcopyrite type structure, characterized by active conductive properties in photovoltaic conversion [1-5]. Among them, the ternary CuInS 2 exhibits a specific interest because of its gap $\mathrm{Eg}(1.5 \mathrm{eV})$ very close to the theoretical optimum for solar energy conversion [6,7]. The electron transitions being direct in this sulfide with a high absorption coefficient $\left(10^{5} \mathrm{~cm}^{-1}\right)$, thin films (a few micrometers) [8,9] can be involved for the building of solar devices, minimizing the cost of solar material.

Numerous methods have been developed to prepare this sulfide. The physical ones, laser removal [10], sputtering [11,12], evaporation [13], co-evaporation [14,15] and electrodeposition $[6,16,17]$ are generally expensive and lead to thin layers with micro-sized particles. Among the chemical ones, the solvothermal and organometallic routes are mainly used. They generally lead to homogeneous powders with grain sizes in the range $3-100 \mathrm{~nm}$. The size of particles is dependent upon the nature of the solvents, precursors and temperature of pyrolysis of the precursors $[18,19]$.

In molten state at temperature in the range of $100-800{ }^{\circ} \mathrm{C}$, the salts are ionic liquids where chemical reactions can be carried out as in usual solvents [20-22]. Molten salts may be used as flux. For instance, $\mathrm{MgFe}_{2} \mathrm{O}_{4}$ can be obtained at temperature as low as $900{ }^{\circ} \mathrm{C}$ by reaction of $\mathrm{MgO}$ and $\mathrm{Fe}_{2} \mathrm{O}_{3}$ in the presence of molten

\footnotetext{
* Corresponding author.

E-mail address: bdurand@chimie.ups-tlse.fr (B. Durand).
}

$\mathrm{Li}_{2} \mathrm{SO}_{4}-\mathrm{K}_{2} \mathrm{SO}_{4}$ eutectic (Eq. (1)), whereas the same transformation in solid state requires a temperature overcoming $1200{ }^{\circ} \mathrm{C}$ :

$\mathrm{MgO}(\mathrm{s})+\mathrm{Fe}_{2} \mathrm{O}_{3}(\mathrm{~s}) \stackrel{\mathrm{Li}_{2} \mathrm{SO}_{4}-\mathrm{K}_{2} \mathrm{SO}_{4}(\mathrm{l})}{\Longrightarrow} \mathrm{MgFe}_{2} \mathrm{O}_{4}(\mathrm{~s})$

Yet the versatility of the process is considerably improved when molten salts are directly involved in the chemical reaction. For the preparation of oxides, two types of transformations have been often considered $[23,24]$ :

- Reactions between a mixed alkaline oxide and a molten divalent metal chloride likely to lead to the formation of $\mathrm{MgFe}_{2} \mathrm{O}_{4}$ at temperature as low as $600{ }^{\circ} \mathrm{C}$ according to the following equation:.

$2 \mathrm{LiFeO}_{2}(\mathrm{~s})+\mathrm{K}_{2} \mathrm{MgCl}_{4}(\mathrm{l}) \rightarrow \mathrm{MgFe}_{2} \mathrm{O}_{4}(\mathrm{~s})+4(\mathrm{Li} / \mathrm{K}) \mathrm{Cl}(\mathrm{l})$

- Reactions between a transition metal salt and a molten alkali nitrate as illustrated by Eq. (3) for the preparation of zirconia can be obtained at temperature as low as $450{ }^{\circ} \mathrm{C}$ :

$$
\begin{aligned}
& \mathrm{ZrOCl}_{2}(\mathrm{~s})+(\mathrm{K}, \mathrm{Na}) \mathrm{NO}_{3}(\mathrm{l}) \rightarrow \mathrm{ZrO}_{2}(\mathrm{~s})+\mathrm{NO}_{2}(\mathrm{~g})+0.5 \mathrm{Cl}_{2}(\mathrm{~g}) \\
& +(\mathrm{K}, \mathrm{Na}) \mathrm{Cl}(\mathrm{l})
\end{aligned}
$$

Previous studies on the behavior of transition metal cations in molten potassium thiocyanate demonstrated the possibility to synthesize sulfides [25]. Only a few papers consider the properties of the powders obtained. Geantet et al. [26] presented the hydrotreating properties of a $\mathrm{MoS}_{2}$ catalyst prepared from thiocyanate melts. Benchikhi et al. [5] proposed a process route to the fabrication of quaternary chalcogenides by reaction in molten $\mathrm{KSCN}$ at $400{ }^{\circ} \mathrm{C}$. 
The main advantage of synthesis by reaction in molten salts lies in the chemical homogeneity of the powders obtained and on the control of the particle size.

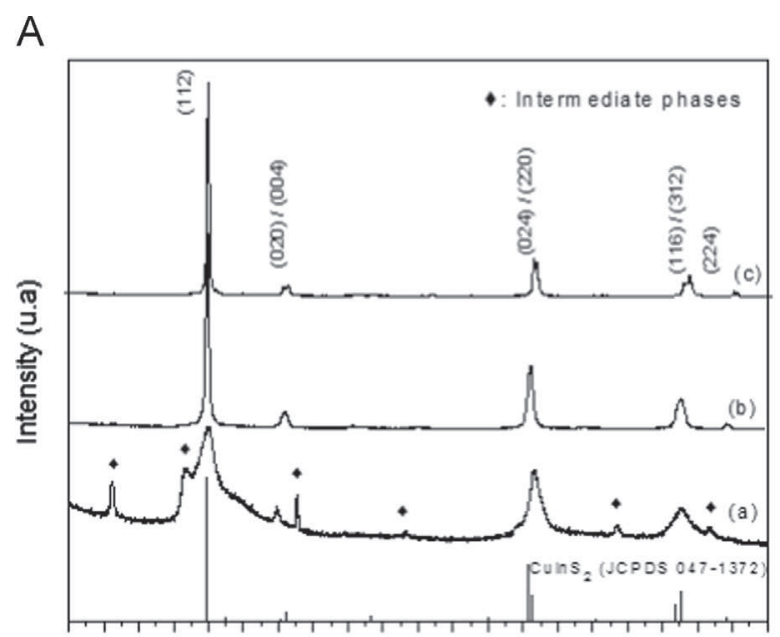

202224262830323436384042444648505254565860

$2 \theta(")$
The present paper describes the synthesis of nano-sized homogeneous powder of CuInS ${ }_{2}$ by reaction of $\mathrm{CuCl}_{2}$ and $\mathrm{InCl}_{3}$ with molten $\mathrm{KSCN}$ at $400{ }^{\circ} \mathrm{C}$. The characteristics of the powder obtained are given.

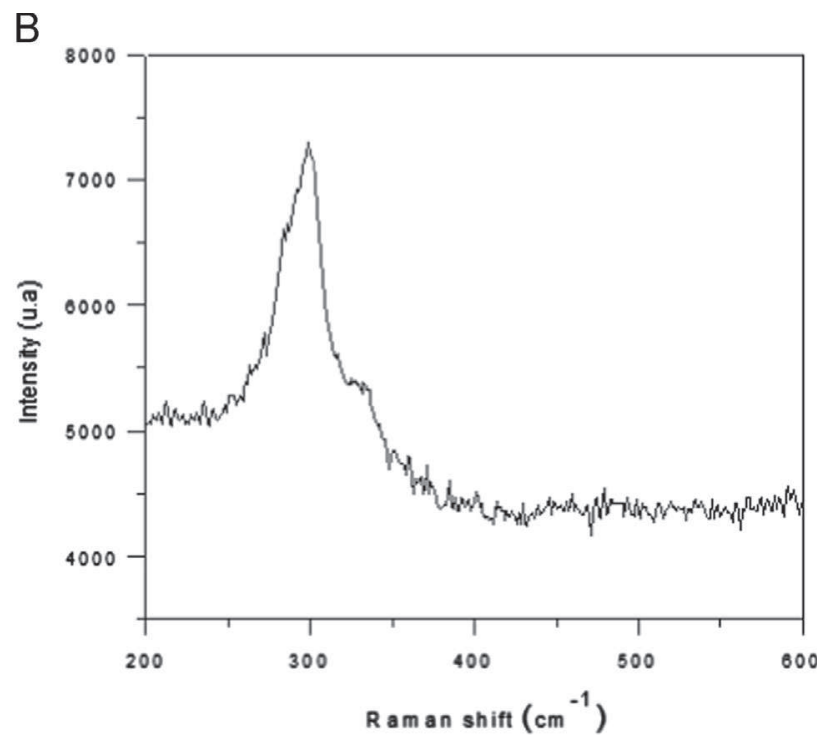

Fig. 1. Structural characterization: (A) RXD patterns of CuInS 2 prepared at $300{ }^{\circ} \mathrm{C}$ (a) $400{ }^{\circ} \mathrm{C}$ (b) and $500{ }^{\circ} \mathrm{C}$ (c). (B) Raman spectrum of CuInS ${ }_{2}$ prepared at $400{ }^{\circ} \mathrm{C}$.
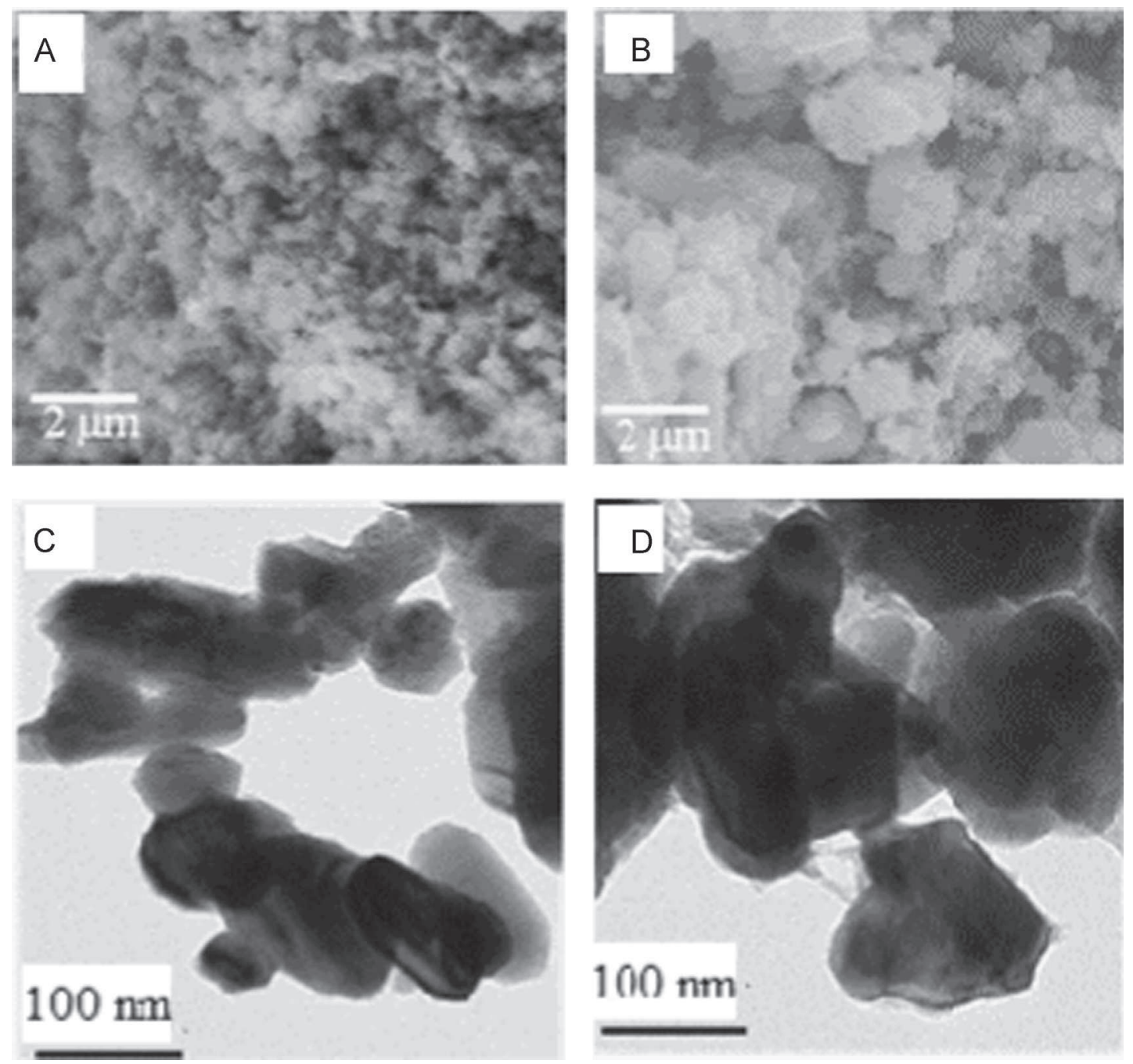

Fig. 2. Morphology: SEM micrographs of CuInS 2 prepared at $400{ }^{\circ} \mathrm{C}$ (a) and $500{ }^{\circ} \mathrm{C}$ (b). TEM micrographs of CuInS 2 prepared at $400{ }^{\circ} \mathrm{C}(\mathrm{c})$ and $500{ }^{\circ} \mathrm{C}(\mathrm{d})$. 


\section{Experimental}

CuInS $_{2}$ was prepared from the following precursors: $\mathrm{InCl}_{3}$ (Aldrich) and $\mathrm{CuCl}_{2} \cdot 2 \mathrm{H}_{2} \mathrm{O}$ (Sigma). KSCN (Prolabo) was used both as solvent and sulfurizating agent. The equimolar mixture of chlorides was added to $\mathrm{KSCN}$ in the molar ratio $\mathrm{SCN} / \mathrm{Cu}=15$. The thermal treatment was performed under nitrogen flow in a vertical furnace at temperatures comprised between 300 and $500{ }^{\circ} \mathrm{C}$ for $24 \mathrm{~h}$. The heating and the cooling rates were stated at $2{ }^{\circ} \mathrm{C} / \mathrm{min}$. The reaction yield reached $70 \%$.

After cooling and solidification of the molten medium, the sulfides were extracted from the excess of salt by washing with water and drying. The black powders obtained were characterized by XRD (Brucker AXS D4, $\lambda C u K \alpha=1.5418 \mathrm{~nm}$ ), SEM (JEOL JSM 6400), TEM (JEOL 2010), specific surface area measurement (BET) (Micrometrics Flowsorb II 2300), Raman (Jobin Yvon Labram HR 800) and UV-visible (UV-1601) spectroscopies.

\section{Results and discussion}

Structural characterization: For the powder prepared at $300{ }^{\circ} \mathrm{C}$, the XRD pattern (Fig. 1Aa) identifies a main phase chalcopyrite $\mathrm{CuInS}_{2}$ (JCPDS 047-1372) besides minor phases which could be metallic sulfides $\left(\operatorname{In}_{2} \mathrm{~S}_{3}, \mathrm{CuS}_{x}\right)$. The peaks of the minor phases are no longer present in the patterns of the sulfides prepared at 400 (Fig. $1 \mathrm{Ab}$ ) and $500{ }^{\circ} \mathrm{C}$ (Fig. 1Ac). The decrease of the full width at half maximum of the XRD peaks of the chalcogenide phase, as the synthesis temperature was raised from 300 to $500{ }^{\circ} \mathrm{C}$, is attributed to the increase of primary crystallite sizes.

Raman investigation was performed to fully characterize the samples. The spectrum of the powder prepared at $400{ }^{\circ} \mathrm{C}$ (Fig. 1B) exhibits a main peak close to $295 \mathrm{~cm}^{-1}$ and a shoulder close to $314-315 \mathrm{~cm}^{-1}$. These signals are consistent with the vibration involving the motion of sulfur atoms of ternary chalcogenides, principal mode $A_{1}$ and secondary mode $B_{2} / E$ observed in the chalcopyrite phase [27-30].

Mechanism of formation: The formation of $\mathrm{CuInS}_{2}$ occurs in three steps $[21,22,31]$ : first the thermal decomposition of KSCN starting at $275{ }^{\circ} \mathrm{C}$ with $\mathrm{S}$ and $\mathrm{S}^{2-}$ formation via reactions (4) and (5), then the reduction of $\mathrm{Cu}^{2+}$ by $\mathrm{SCN}^{-}$involving the formation of a complex of transition via reaction (6) and lastly the formation of the chalcopyrite phase via reaction (7):

$\mathrm{SCN}^{-}=\mathrm{CN}^{-}+\mathrm{S}$,

$2 \mathrm{CN}^{-}+\mathrm{S}=\mathrm{S}^{2-}+(\mathrm{CN})_{2}$,

$\mathrm{Cu}^{2+}+2 \mathrm{SCN}^{-}=\left[\mathrm{Cu}(\mathrm{SCN})_{2}\right]^{*}=\mathrm{Cu}^{+}+\frac{1}{2}(\mathrm{CN})_{2}+\mathrm{SCN}^{-}+\mathrm{S}$

$\mathrm{Cu}^{+}+\mathrm{In}^{3+}+2 \mathrm{~S}^{2-}=\mathrm{CuInS}_{2}$.

Morphological characterization: SEM observation of the samples synthesized at 400 and $500{ }^{\circ} \mathrm{C}$ (Fig. 2a and b) shows largely agglomerated particles with a poly-disperse size distribution. The size of agglomerates increases with increasing temperature synthesis. The agglomerates (Fig. 2c and d) are constituted of nano-sized primary crystallites with more or less elongated shape. It is noticed (Table 1) that the mean sizes of particles calculated from the specific surface area values, assuming mono-disperse spherical particles, are higher than the sizes observed on TEM micrographs. This difference is attributed to the agglomeration of particles.

Measurement of the band gap Eg: The energetic value of the band gap of a semiconductor determines the part of the solar spectrum that could be theoretically absorbed by the material. From the UV-visible absorption spectrum of the sulfide powder
Table 1

Morphological characteristics. (The mean size of particles is calculated from the specific surface area according to the formula $D=6 / d S, D$ is the mean diameter, $d$ the density and $S$ the specific surface area.).

\begin{tabular}{llll}
\hline $\begin{array}{l}\text { Temperature } \\
\left({ }^{\circ} \mathrm{C}\right)\end{array}$ & $\begin{array}{l}\text { Specific surface area } \\
\left(\mathrm{m}^{2} / \mathrm{g}\right)\end{array}$ & $\begin{array}{l}\text { Grain size }(\mathrm{MET}) \\
(\mathrm{nm})\end{array}$ & $\begin{array}{l}\text { Mean grain size } \\
(\mathrm{nm})\end{array}$ \\
\hline 400 & 5.9 & $70-100$ & 200 \\
500 & 3.5 & $130-150$ & 340 \\
\hline
\end{tabular}

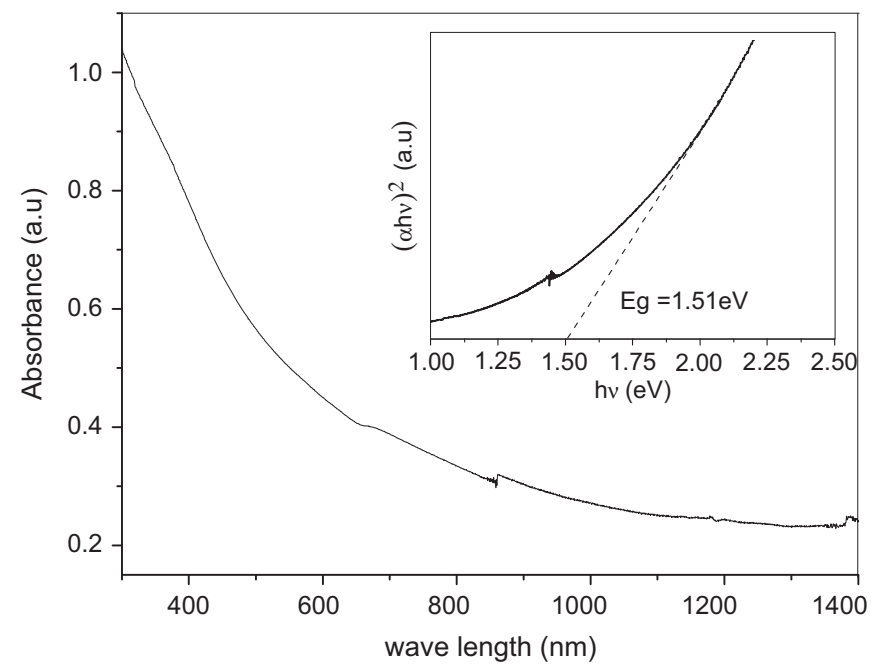

Fig. 3. UV-visible absorption spectrum of CulnS $S_{2}$ prepared at $400{ }^{\circ} \mathrm{C}$.

prepared at $400{ }^{\circ} \mathrm{C}$ (Fig. 3), the band gap Eg of the semiconductor with a direct transition is determined using the following equation [32]:

$(\alpha h \nu)=A(h \nu-\mathrm{Eg})^{1 / 2}$

Where $\alpha$ is the absorption coefficient $\left(\mathrm{cm}^{-1}\right), h \nu$ the energy of the incident photons $(\mathrm{eV})$ and $A$ a constant. The Eg value of $1.51 \mathrm{eV}$ is determined by the intersection of the linear part of the curve $(\alpha h \nu)^{2}$ versus $h \nu$ (inset Fig. 3). This value is in agreement with the ones of the literature, $1.55 \mathrm{eV}$ for single crystals [33] and $1.44 \mathrm{eV}$ for CuInS ${ }_{2}$ films deposited by CVD [34] or $1.50-1.52 \mathrm{eV}$ for samples prepared by pulverization of indium and copper followed by a sulfuration step [35].

\section{Conclusion}

The chalcopyrite phase $\mathrm{CuInS}_{2}$ was prepared by the reaction in a molten salt. The powder obtained in $\mathrm{KSCN}$ medium at $400{ }^{\circ} \mathrm{C}$ for $24 \mathrm{~h}$ with the ratio $\mathrm{KSCN} / \mathrm{Cu}=15$ is constituted of crystallites with sizes in the range $70-100 \mathrm{~nm}$ and exhibits a specific surface area close to $6 \mathrm{~m}^{2} / \mathrm{g}$ and a gap Eg close to $1.5 \mathrm{eV}$ suitable for application in the photovoltaic conversion of solar energy.

\section{Acknowledgments}

This work was supported by two French-Moroccan projects: Volubilis Partenariat Hubert Curien (PHC no. MA 09 205) and Projet de Recherches Convention Internationale du CNRS (CNRSCNRST no. w22572). 


\section{References}

[1] Nadenau V, Hariskos D, Schock HW, Kreijci M, Haug F, Tiwari A, et al. App Phys 1999;85:534-42.

[2] Aggour M, Störkel U, Murrell C, Campbell SA, Jungblut H, Hoffmann, et al. Thin Solid Films 2002;403-404:57-61.

3] Hironori K. Thin Solid Films 2005;480-481(1):426-32.

[4] Hironori K, Kotoe S, Tsukasa W. Sol Energ Mater Sol Cells 2001:65(1-4):141-7.

[5] Benchikhi M, Zaberca O, El Ouatib R, Durand B, Oftinger F, Balocchi A, et al. Mater Lett 2012;68:340-3.

[6] Scragg JJ, Dale PJ, Peter LM. Thin Solid Films 2009;517:2481-4.

[7] Arici E, Sariciftci NS, Meissner D. Adv Funct Mater 2003;13:165-71.

[8] Pathan HM, Lokhande CD. Appl Surf Sci 2004:11:239-54.

[9] Katagiri H, Sasaguchi N, Hando S, Hoshino S, Ohashi J, Yokota T. Sol Energy Mater Sol Cells 1997;49:407-14.

[10] Shuaibov AK, Churchman MP, Dashchenko AI. Tech Phys Lett 2003;29:408-10.

11] Jaffe JE, Zunger A. Phys Rev B 1983;28:5822-47.

[12] Seol JS, Lee SY, Lee JC, Nam HD, Kim KH. Sol Energy Mater Sol Cells 2003;75:155-62.

[13] Kazmerski LL, Sanborn GA. J Appl Phys 1977;48:3178-80.

[14] Scheer R, Walter T, Schock HW, Fearheiley ML, Lewerenz HJ. Appl Phys Lett 1993;63:3294-6.

[15] Tanaka T, Kawasaki D, Nishio M, Guo Q, Ogawa H. Phys Status Solidi C 2006;3:2844-7.

[16] Herrero J, Ortoga J. Sol Energy Mater 1990;20:53-65.

17] Hodes G, Cahen D. Sol Cells 1986;16:245-54.

[18] Nyari T, Barvinschi P, Baies R, Vlazan P, Barvinschi F, Dékany I. J Cryst Growth 2005:275:2383-7.
[19] Gardner JS, Shurdha E, Wang C, Lau LD, Rodriguez RG, Pak JJ. J Nanopart Res $2008 ; 10: 633-41$

[20] Charlot G, Tremillon B. les réactions dans les solvants et les sels fondus. Gauthier-Villars; Paris; 1963; 486 (Chapter XV).

21] Eluard A, Tremillon B. J Electroanal Chem 1967;13:208-12.

22] Collado S, Laca A, Diaz M. J Hazard Mater 2010;177:183-9.

[23] Durand B. Ceramic Powders. In: Vincenzini P, editor. Amsterdam: Elsevier Science. Publishing. Co.; 1983. p. 413-20.

[24] Durand B, Roubin M. Mater Sci Forum 1991;73-75:663-8.

[25] Kerridge DH, Walker SJ. Inorg Nucl Chem 1977;39:1579-85.

[26] Geantet C, Kerridge DH, Decamp T, Durand B, Breysse M. Mater Sci Forum 1991;73-75:693-8.

[27] Guha P, Das D, Maity A-B, Ganguli D, Chaudhuri S. Sol Energy Mater Sol Cells 2003;80:115-30

[28] Kondo K, Nakamura S, Sato K. J Appl Phys 1998;37:5728-36.

[29] Das K, Panda S-K, Gorai S, Mishra P, Chaudhuri S. Mater Res Bull 2008;43:2742-50.

[30] Palm J, Jost S, Hock R, Probst V. Thin Solid Films 2007;515:5913-6.

[31] Tian Y, He Y, Zhu Y-F. Chem. Let 2003;32:768-9.

[32] Gungor T, Tolunay HJ. Non-Cryst Solids 2001;282:197-202.

[33] Shay JL, Wernick JH. Ternary chalcopyrite semiconductors: growth, electronic properties and applications. Oxford New York: Pergamon Press; 1975.

34] Henderson DO, Mu R, Ueda A, Wu MH, Gordon EM, Tung YS, et al. Mater Des 2001;22:585-9.

[35] Klaer J, Bruns J, Henninger R, Siemer K, Klenk R, Ellmer K, et al. Semicond Sci Technol TI 1998;13:1456-8. 